\title{
MOBILITY, RETURN FOR DEVELOPMENT AND SENSE OF EUROPE: NARRATIVES OF MOLDAVIAN IMMIGRANTS RETURNING FROM THE EUROPEAN UNION
}

\begin{abstract}
Silvia Marcu
The article links migration, cross-border mobility and return for development embedded in terms of identity and approach to sense of Europe. Taking into account the global changes in Moldova, the paper examines the perceptions of mobility, return and identity of the Moldovans engaged in emigration in the countries of the European Union (EU). Utilising a multi-discipline approach and an in-depth qualitative interview technique, this article seeks to analyze how mobility and return can support social change and development of the country, and argues that people, who cross EU borders, living through the experience of emigration, acquire a pro-European mentality.
\end{abstract}

Keywords: mobility, border, Moldova, return, development, European Union.

\section{Introduction $^{1}$}

Over the last two decades, there have been profound transformations in the territory and society of Eastern Europe, characterized by three fundamental factors that interact with each other: mobility, identity and development. One of the countries that is sensitive to this global issue is Moldova, which was created in 1991 following the collapse of the Soviet Union. It is located past the eastern border of the European Union (EU) and has a complex history and a mix of multiple identities ${ }^{2}$. Moldova is, then, a multi-ethnic country divided by a still-unresolved secessionist conflict

\footnotetext{
* Instituto de Economía, Geografía y Demografía (IEGD), Centro de Ciencias Humanas y Sociales (CCHS), Consejo Superior de Investigaciones Científicas (CSIC). Madrid/Spain.

${ }^{1}$ This article comes as a result of the research project entitled: "Eastern European Migration to Spain in the context of border geopolitics: circulatory mobility and return," (CSO 2010-14870), with funding from the Spanish Ministry of Science and Innovation and coordination by the author.

${ }^{2}$ CHINN, Jeff. Moldovans: Searching for Identity.
} 
(1991-1992) as well as conflicting interpretations as to national and ethnic identity $^{3}$. Discourse about identity has been notable since 1991 in a territory where economic and social crises forced its citizens to seek job opportunities in the developed countries of the EU. Linked to the mobility process, the return of immigrants became ever more obvious, while the ease in which Moldovans can obtain Romanian citizenship expanded the process of crossborder mobility into Europe, especially following Romania's entry into the EU. Return does contribute to national development since Moldova is a country that practically lives thanks to emigration: 38 percent of the GNP is derived from emigrants' remittances ${ }^{4}$.

The EU has become an increasingly important symbol in the Republic of Moldova. During the past ten years, Europe has gained a strong presence in the country, partly due to the enlargement of the EU, but also because of the important role that the symbolic geography of 'Europe' plays in domestic politics. Romania has been re-imagined in relation to Europe, in part because has joined the EU, while neighbouring Moldova has not, but the particular ways in which Romania is re-imagined are also related to the complex history shared by the two countries. Much, but not all, of Moldova's territory previously belonged to Romania, and the legitimacy of the current border has long been contested in ethnic, linguistic, historical, and political terms.

This article analyzes the cross-border discourse of mobility on the part of Moldovans engaged labor mobility in the countries of the EU. It examines the relationship between mentality, values and migration to capture the influence of cross-border mobility in the reconfiguration of the identity of persons who emigrate while taking into account the already complex Moldovan identity.

The paper explores the way in which migrants act as authors of their own lives and the way that their lives, in turn, act to author them. By examining immigrants' discourse, the paper argues that the fact that people who cross EU borders, living through the experience of mobility, acquire a pro-European mentality. The return of these immigrants and their capacities for enterprise support not only development, but also social change in Moldova.

The article poses the following research questions: Firstly, what is the role of mobility in the development of a country and what is the role played by borders in interpreting the sense of being European? And secondly, the

${ }^{3}$ KING, Charles. Marking time in the middle ground: contested identities and Moldovan foreign policy; MARCU, Silvia. The Geopolitics of the Eastern Border of the European Union: The Case of Romania-Moldova-Ukraine.

${ }^{4}$ According to IOM specialists L. Vasilova and T. Jordan, interviews collected in April 2011 showed that $90 \%$ of remittances were used for consumables, while $10 \%$ were destined to development. 
article confirms how mobility and the potential construction of a supranational identity that is closer to Europe can underscore social change and development in Moldova. How do migrants create their sense of Europe?

In this paper, 'reconstruction of identity' is to be interpreted as the incorporation of new elements in the framework of Moldovans' identity; these elements are capable of creating openness and a change in mentality, according to European values. My particular concern here is with the ways in which different senses of identity impact where people are willing to go and work. If I could establish a link between identity and mobility and show that it is possible to modify and enrich identity through mobility, then it provides a demonstration of the link between them.

After a presentation of the theoretical and methodological background of the study, the empirical chapter presents an analysis of the narratives of returned Moldavian immigrants. The paper ends with some reflections on how mobility, return and the creation of a new and more European identity can support social change and development of the country.

\section{Mobility and identity in the European context}

Following the advance of EU borders towards Eastern Europe, there was a fundamental change in the nature of border and the identity of the migrants as a result of the intense process of mobility ${ }^{5}$. There are two perspectives on borders that have come to dominate discussion of European borders: securitized borders associated with the process of (re)bordering and borderless Europe (the single market and its associated mobilities). While rebordering highlights the increasing securitization and impermeability of borders associated with the 'Schengenland' model of enhanced mobility within a common space protected by 'hard' external borders, the idea of 'undivided Europe ${ }^{\prime 6}$ posits an extended communicative and economic space represented by the notion of 'network Europe', connectivity and fluidity

Linked to mobility, in recent years, the study of citizenship and identity in the wider Europe, has taken on some dimensions, in part because of intensified transnational mobility. As transnational mobility has forged new cultural formations ${ }^{8}$, it also brings about challenges to how we understand identity and citizenship ${ }^{9}$.

\footnotetext{
${ }^{5}$ AGNEW, John. Borders on the mind: re-framing border thinking. GLICK SCHILLER, Nina; BASCH, Linda; BLANC-SZANTON, Cristina. Transnationalism: A new analytic framework for understanding migration.

${ }^{6}$ VAN HOTUM, Henk. Human blacklisting: the global apartheid of the EU's external border regime. ${ }^{7}$ COOPER, Anthony; RUMFORD, Chris. Monumentalising the Border: Bordering Through Connectivity.

${ }^{8}$ FAIST, Thomas. Migrants as Transnational Development Agents: An Inquiry into the Newest Round of the Migration-Development Nexus.

${ }^{9}$ FOURON, Georges; GLICK SHILLER, Nina. All in the Family: Gender, Transnational Migration, and
} 
In a wider Europe, identity should be differentiated from the support to European integration, and is not perceived as mutually exclusive from other identities, such as national and local identifications ${ }^{10}$. They are thus seen as complementary rather than incompatible ${ }^{11}$ and conceptually different, even if it is true that both are often related in the minds of people ${ }^{12}$.

In this context, the identity of migrants from Eastern Europe is built and re-built and is perceived as a search, a kind of individual project, in which each person has the responsibility of organizing life according to his or her own choices. Individuals may hold many different identities which may or may not conflict. Thus, it may be helpful to see identities as parts of a repertoire that can be selectively activated under different circumstances.

In Moldova, the mobility has been a factor having a strong demonstrative and symbolic influence and has had an impact on the country in three ways: firstly, by providing assistance to support the country in overcoming some poverty-related problems; secondly, by influencing policy agenda in the area of human development; and thirdly, by 'Europeanizing' Moldova's people themselves. Thus, Europeanisation is discussed in terms of globalisation ${ }^{13}$. As Fligstein and Mérand argue ${ }^{14}$, much of what people call "globalisation" in Europe is in fact Europeanisation. The patterns of mobility and particular negotiations around identity and citizenship that link Moldovan migrants could be seen as what Rouse ${ }^{15}$ has called a tightly woven together community defined by a transnational circuit. These social practices challenge discreet boundaries around what it means to be a citizen of a single state, instead suggesting that we need to think in more nuanced ways about the complexity of multiple and shifting citizenships ${ }^{16}$.

\section{Migration and return for development from a transnational perspective}

Linked to the complex issue of identity, in a wider Europe, research on migration and development in particular are undergoing a transnational

\footnotetext{
the Nation-State.

${ }^{10}$ RISSE, Thomas. European institutions and identity change: what have we learned? ROTHER Nina; NEBE, Tina. More Mobile, More European? Free Movement and EU identity.

${ }^{11}$ BRUTER, Michael. Citizens of Europe? The Emergence of a Mass European Identity.

${ }^{12}$ GRUNDY, Sue; JAMIESON, Lynn. European Identities: From Absent-Minded Citizens to Passionate Europeans.

${ }^{13}$ BECKFIELD, Jason. European Integration and Income Inequality.

${ }^{14}$ FLIGSTEIN, Neil; MÉRAND Frederic. Globalization or Europeanization? Evidence on the European Economy since 1980.

${ }^{15}$ ROUSE, Roger. Mexican migration and the social space of post-modernism.

${ }^{16}$ COUTIN, Susan. Nations of Emigrants: Shifting Boundaries of Citizenship in El Salvador and the United States.
} 
turn. The migration and the development literature have traditionally been two separate areas of study. As explained Skeldon ${ }^{17}$ one of the difficulties of talking about migration and development is that we are dealing essentially with two 'black boxes'. However, as the author points out, migration cannot be separated from development.

The conventional conception of the relationship between migration and development has evolved through three phases. First, in the 1950s and 1960s, migration was perceived as having a positive effect on migrant-sending societies ${ }^{18}$. Second, in the 1970s and 1980s, a more pessimistic approach perceived emigration as a sign of underdevelopment. The outmigration of qualified workforce, or so-called brain drain, was particularly criticised. The present enthusiasm for the development potential of migration introduces a third phase starting in the early 1990s and linking back to the optimism of the first. The focus is now placed on the transfer of financial remittances, knowledge and skills from the migrants' country of residence to their country of origin and the celebration of temporary labour migration ${ }^{19}$.

Researchers highlight the linkages between migration flows and investment and trade relations between sending and receiving countries ${ }^{20}$. Another strand of the migration and development debate highlights the role of migrants in transferring knowledge and competences to their country of origin $^{21}$. Finally, a strand of research examine a relatively new concept of 'social remittances' or the ideas, practices and social capital that flow from migrant receiving- to sending-country communities ${ }^{22}$. Taking into account the Skeldon' argument ${ }^{23}$, in this work I integrate the issues of migration and return for development in the wide framework of transnationalism.

In the last decade, transnational migration theory has questioned this separation by examining migrants' simultaneous connections in their host and their home countries ${ }^{24}$. The theorists of the transnational perspective give particular emphasis on social ties and networks across the borders of nation-

\footnotetext{
${ }^{17}$ SKELDON, Ronald. Migration and development over twenty years of research: progress and prospects.

${ }^{18}$ DE HAAS, Hein. Migration and development: a theoretical perspective.

19 KING, Richard; POVRZANOVI Frykman; VULLNETARI, Jullie. Migration, transnationalism and development on the Southeastern flank of Europe.

${ }^{20}$ GOULD, David. Immigrant Links to the Home Country: Empirical Implications for US Bilateral Trade Flows.

${ }^{21} \mathrm{HADZIGEORGIOU}$, Andreas. Migration as Trade Facilitation: Assessing the Links between International Trade and Migration; SANDERSON, Matthew; KENTOR, Jeffrey. Foreign direct investment and international migration: A cross-national analysis of less-developed countries, 1985-2000; JANSEN, Marion; PIERMARTINI, Roberta. Temporary Migration and Bilateral Trade Flows.

22 SANDERSON, KENTOR, op. cit.

${ }^{23}$ SKELDON, op. cit.

${ }^{24}$ LEVITT, Peggy; LAMBA-NIEVES, Deepak. Social Remittances Revisited.
} 
states $^{25}$. In this context, the transnational perspective on migration moves between 'temporary', 'permanent' and 'return' migration ${ }^{26}$ emphasizing that the life of migrants is increasingly characterised by circulation and simultaneous commitment to two or more societies ${ }^{27}$.

Following the transnational perspective, this paper conceptualizes 'return' as a dynamic and open-ended process rather than at once-andfor-all move from the host to the home country. Such an approach recognizes that 'return' may not necessarily be permanent and often involves mobility between the host and home country. King ${ }^{28}$ identifies a typology of return that is inclusive not only of permanent, but also occasional, seasonal, and temporary returnees. Return, in other words, should not be intended as a "closure of the migration cycle, but rather as "one of the multiple steps of a continued movement" so that the notion is able to incorporate a whole range of people with differing mobility patterns.

From a development perspective, Black and Gent $^{29}$ argued that return is far from unproblematic, raising questions about the conditions and the voluntariness of return and the ability of returnees to reintegrate, what Van Houte and Tine ${ }^{30}$ defined as 're-embeddedness'. Both studies distinguished between the individual sustainability of return and whether return contributes to development. The economic downturn, which began during 2007, has the potential to exacerbate these already complex processes. In particular, the global economic crisis increases the likelihood of migrants returning to countries of origin as a result of unemployment, decreasing wages, clamping down on irregular migration. As such, it raises the spectre of decreasing remittance flows, disenchanted returnees swelling the already high levels of the un-employed and under-employed, potentially contributing to social unrest and political instability.

For Moldavian migrants, return has been dealt with while referring to the ways in which returnees are successful in adapting themselves to their home environment, at all levels. They know how to take advantage of the "European identity attributes" they acquired abroad, with a view to

${ }^{25}$ PORTES, Alejandro, GUARNIZO, Luis; LANDOLT, Patricia. The Study of Transnationalism: Pitfalls and Promise of an Emergent Research Field; VERTOVEC, Steve. Conceiving and Researching Transnationalism.

${ }^{26}$ AMASSARI, Savina; BLACK, Richard. Harnessing the potential of migration and return to promote development: applying concepts to West Africa.

${ }^{27}$ DE HAAS, Hein. The migration and development pendulum: a critical view of current research and policy.

${ }^{28}$ KING, Richard. Generalizations from the history of return migration.

${ }^{29}$ BLACK, Richard; GENT, Saskia. Sustainable return in post-conflict contexts.

${ }^{30}$ VAN HOUTE, Marieke; TINE, Davids. "Development and return migration: from policy panacea to migrant perspective sustainability". 
distinguishing themselves from the locals. As rightly point Chapman and Prothero $^{31}$ thanks to the transnationalist approach to international migrations, in general, and to return, in particular, it is possible to question the binary structuralist vision of cross-border movements, taking into account the circularity of migration movements which facilitates migrants' mobility and consequently their approach to the European values.

\section{Moldovans in the EU}

Moldova is a country of emigrants. According to official government estimates, more than one quarter of the Moldovan labor force is currently living and working abroad with the actual figure differing according to sources and likely topping 540,000. ${ }^{32}$ As a result, migrants are a major source of income for the national economy, with an estimated 1.9 billion in remittances from those abroad in 2008 accounting for 38\% of Moldova's GDP: the secondhighest rate globally after Tajikistan. The country's real GDP per capita is the lowest in Europe and Moldova is classified as a low-income country by the World Bank ${ }^{33}$.

The EU countries receiving the greatest numbers of Moldovans are Italy, Romania, Germany, Spain and the United Kingdom (Fig.1), where, in addition, immigrant networks that promote circulation and irregularity have been set up $^{34}$.

\section{FIGURE 1}

Moldovans immigrants (EU)

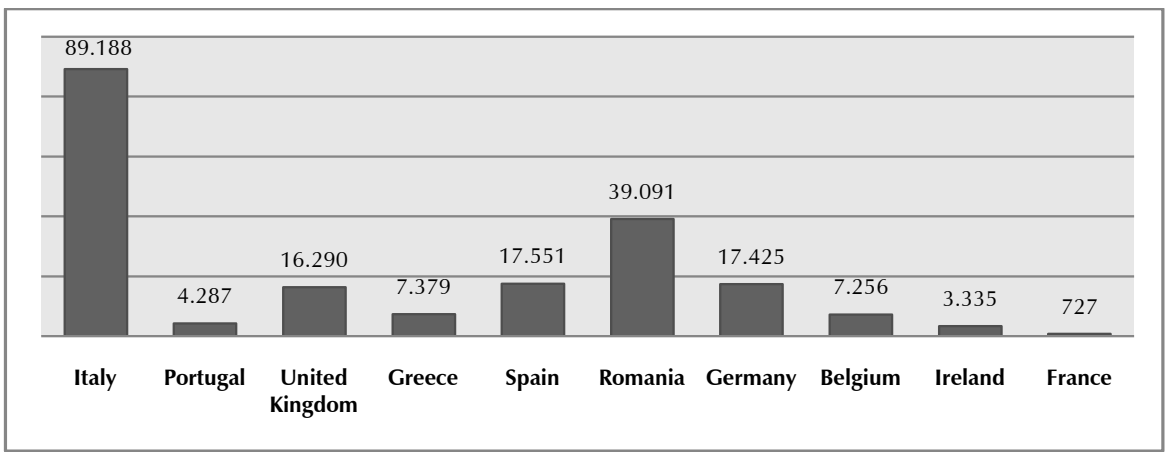

Source: Ministry of Exterior, Chisinau, 2012.

\footnotetext{
${ }^{31}$ CHAPMAN, Murray; PROTHERO, Mansell. Themes on circulation in the Third World.

${ }^{32}$ Of these, 237,690 live in countries of the EU.

33 The GDP per capita was 2,500 USD in 2008 (7,800 USD in Ukraine; 12.500 USD in Romania; and 33,800 USD in the European Union. Cf. World Bank: Report No. 55195-Moldova; April 4, 2011).

${ }^{34}$ RUSNAC, Gheorghe; MOŞNEAGA, Valeriu; MORARU, Victor; ŢURCAN, Valentin. Faţetele unui proces: migraţia forței de muncă din Republica Moldova în Italia.
} 
Current statistics show that there is a notable reduction in the population of Moldova as a consequence of emigration. While in 1989 there were 4 million Moldovans, the 2004 census showed that this number had dropped to 3.5 million.

The process of family reunification also has great relevance. The rate of women emigrating is ever greater. According to statistics compiled by the Moldovan Border Service ${ }^{35}$, an increasing number of pre-school children have crossed over the border in the last year. In Italy, 89,188 Moldovans became legal residents, while in Spain there were 17,551. Of these, 13,000 in Italy had dual Moldovan/Romanian citizenship, while in Spain this amounted to 6,123 people. This demonstrates the growing number of Moldovans who are resorting to Romanian citizenship in order to circulate freely within the EU.

In Moldova, there is an important link between mobility, identity and development. Firstly, mobility is closely tied to identity, given that since 2007 the majority of Moldovans have sought to emigrate and obtain Romanian citizenship by relying on their Romanian ethnicity. Secondly, there is the nettlesome problem of economic development linked to remittances and the return of emigrants. If this equation can be solved, the mobility and return of immigrants could contribute to the development of the country and to the benefit of the immigrants themselves.

\section{Methodology}

Our framework was developed from qualitative fieldwork with emigrant returnees to Moldova ${ }^{36}$. I had 54 in-depth interviews in Moldova. Besides Chisinau, the interviews were conducted in the cities of Anenii Noi, Hincesti and Straseni, from where the greatest number of Moldovans emigrated to the $\mathrm{EU}$ and returned $^{37}$ (Fig. 2).

I interviewed 24 men and 20 women of working age who had returned from EU countries. In 27 cases, their migrant experience aided them in creating a business in Moldova by using the social, human and financial capital they had gained in the EU. In the other 17 cases, the interviewees' experience was difficult due to the precarious legal and juridical situation in the destination country. The interviewees had emigrated over the last 10 years to Italy (12), Spain (10), United Kingdom (9), Ireland (3), Portugal (5),

\footnotetext{
${ }^{35}$ Cf. <http://www.border.gov.md $>$.

${ }^{36}$ During the months of July 2010 and April 2011, I undertook field work within the framework of a project on mobility and return.

${ }^{37}$ Even though previously I contacted the local counsellors later, I used the snowball technique and interviewed returning Moldovans in public places (official offices, and cafés) or in their homes.
} 
and Greece (5), having returned over the last year, even while some continue to engage in cross-border mobility.

\section{FIGURE 2}

\section{Fieldwork area}

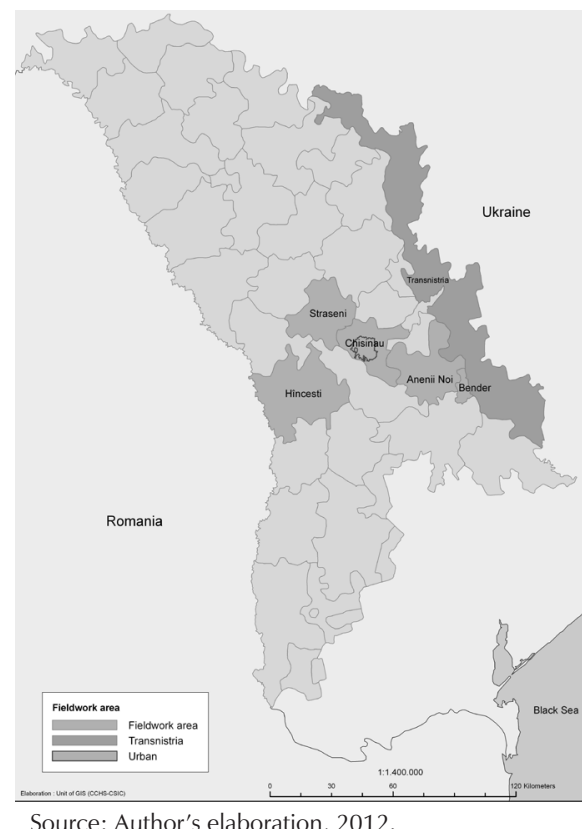

Source: Author's elaboration, 2012.

I also interviewed 10 officials who specialize in the management of immigration in Moldova: the IOM coordinator in Chisinau, researchers and professors at the Academy of Science and Chisinau State University, local councillors in Hincesti and Anenii Noi and the town mayor of Varnita. I completed the field work in Bucharest and the headquarters of the National Authority for Romanian Citizenship (April 2011), where I interviewed the director of communications in order to better understand the process of granting Romanian citizenship to Moldovans, and I also spoke with Moldovans seeking Romanian citizenship ${ }^{38}$.

The research is characterized by its explorative nature, which is why it has certain limitations (the relatively small number of participants $-44+9$ Romanian-speaking officials). Thus, I cannot determine exactly what the opinion of the other localities' inhabitants is and, moreover, I cannot make assumptions about the view of other ethnic groups on the matter.

\footnotetext{
${ }^{38}$ Aside from the interview with the IOM coordinator, the rest of the interviews were conducted entirely in Romanian and then translated into English.
} 
Utilizing a focus taken from grounded theory ${ }^{39}$, I analyzed interview transcriptions and coded them (with the Atlas Ti, 6.2 Program) according to the issues that emerged. From the beginning, I followed Barth's theory ${ }^{40}$, and on the presumption of disorder, later tried to organize and explain data according to the ground theory method. By using open coding, both axial and selective, the issues that emerged from the interviews were organized and analyzed as follows.

\section{Cross - border experiences: the dual citizenship strategy}

When Romania joined the EU on 1 January 2007, the boundaries of the EU changed once again. The border between Romania and Moldova along the River Prut not only divides two sovereign states but also forms the current external border of the EU. (Fig.3)

\section{FIGURE 3}

\section{Romanian-Moldovan Border Area}

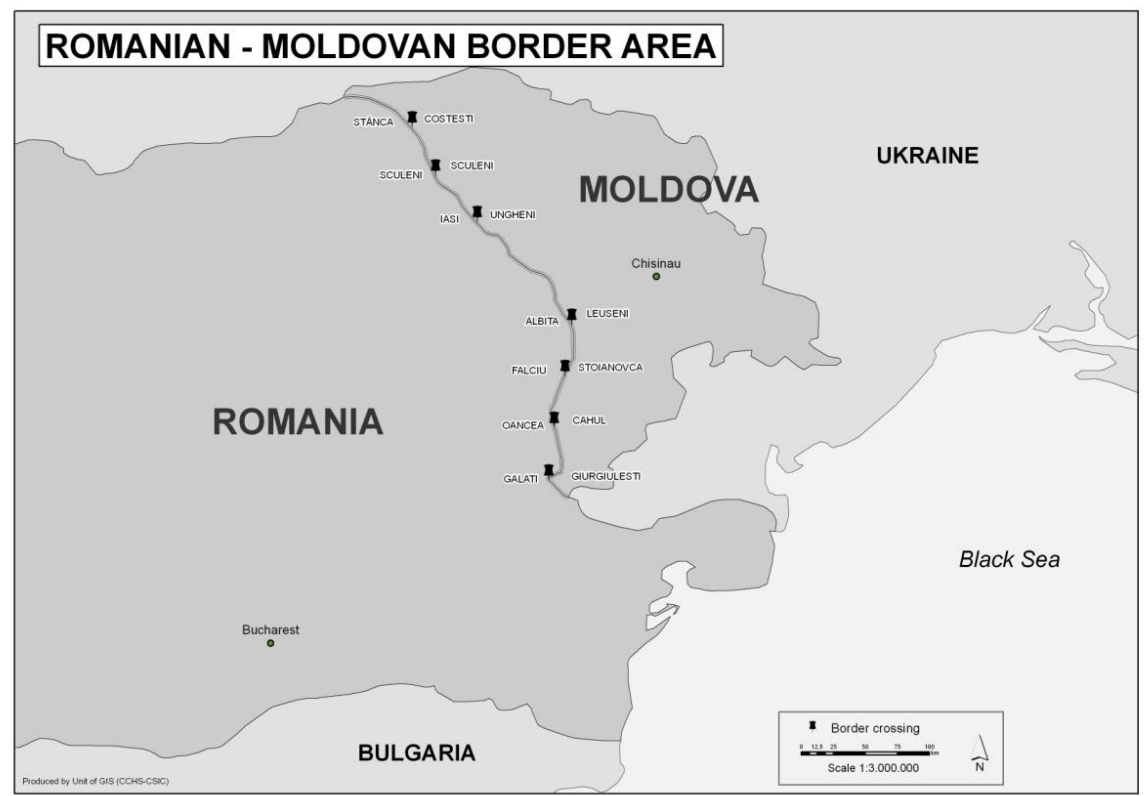

Source: Author's elaboration, 2012.

\footnotetext{
${ }^{39}$ GLASER, Barney; STRAUSS, Anselm. The discovery of grounded theory: strategies for qualitative research. Grounded theory is a method that begins by collecting data and by means of the data there are detected codes by which information is extracted. The codes are grouped according to similar concepts from which categories that offer a basis for a reverse-engineering theory or hypothesis are formed.

${ }^{40}$ BARTH, Fredrick. The Analysis of Culture in Complex Societies.
} 
Hence, the River Prut gains a special significance: it divides the 'west' (Romania) from the 'east' (Moldova) and, furthermore, the Romanian region of Moldova from the Republic of Moldova ${ }^{41}$.

Therefore, citizens of Moldova are required to have visas in order to travel within EU countries and also to cross the border into Romania ${ }^{42}$. Moreover, Moldova is affected by chronic political, social and economic instability and a lack of opportunities for current migrants and their children. As a result, what begins as temporary labor migration sometimes turns into progressive depopulation.

The interviewees recounted their border experience and the difficulty in departure. Around 70\% said that they had purchased the exit visa, while 30\% emigrated illegally upon receiving Romanian citizenship. Males, while they also purchased their visas, had a largely positive experience upon obtaining them, while women who had been tricked by criminal organizations had to pay excessively large sums of money to obtain a visa, or were abandoned before reaching their destination.

It is a difficult experience to cross a border. We ask ourselves, 'Why do we have to go through this?' I walked 72 hours, and the Romanian gangs tricked me. In my opinion, there is no competence; the government border agents are not serious. You leave your papers for them to examine, and then you wait for a whole day. On the Romanian border, it is very difficult at Albita. This is also to be noted when you arrive in Spain and become an irregular immigrant ${ }^{43}$.

The strategy used by Moldovans to cross borders is to obtain Romanian citizenship. The 1991 Law on Romanian Citizenship ${ }^{44}$ enacted two major innovations in Romanian citizenship legislation. First, it allows Romanian citizens to hold dual citizenship; second, it goes beyond the commonly accepted standard on repatriation, enabling individuals who re-acquire Romanian citizenship to retain not only their first citizenship, but also their domicile abroad. According to its main initiators, the motivations behind the new liberal citizenship law were democratic, intending to allow former Romanian citizens to reacquire, upon request, their lost rights. The main

\footnotetext{
${ }^{41}$ MARCU, Silvia. Opening the Mind, Challenging the Space: Cross-border Cooperation between Romania and Moldova.

${ }^{42}$ Since the signing of a 2009 treaty that allowed small amounts of border traffic between Romania and Moldova, people residing along the border are not required to have a visa but merely a permit and a valid passport.

${ }^{43}$ Interview, 15 July 2010. Female returning from Spain, age 53, Straseni.

${ }^{44}$ Romanian citizenship Law 21/1991. Cf. <http://legislatie.resurse-pentrudemocratie.org/21_1991. php > ; <http://www.romanianpassport.co.il/english/romanian-citizenship-law/>.
} 
beneficiaries of the law are the inhabitants of the former Soviet Socialist Republic of Moldova and the provinces of Northern Bukovina and Southern Bessarabia, in Ukraine. Because, the inhabitants of Bukovina and Bessarabia were stripped of their Romanian citizenship following the Soviet occupation (1940-1942 and 1944-1991), the 1991 law was conceived specifically to enable them to recover that legal status.

Dual citizenship became an increasingly important issue following the 2003 local elections, and in November 2003, the Moldovan parliament passed a law that allowed Moldovans to hold dual citizenship. While Romania had been pressing for this reform for some time, those Moldovans who held Ukrainian and Russian passports also benefited from this change. The amendment eliminated the previous prohibition on holding dual citizenship and from an identity perspective demonstrated that an individual could be both a Romanian and a Moldovan simultaneously.

Both public opinion and the various media in Moldova and Romania ${ }^{45}$ contend that the integration of 3.5 million Moldovans by the EU commenced when Moldovans ${ }^{46}$ began to obtain Romanian citizenship. "We are a country of Moldovans with Romanian citizenship who speak Russian", noted a man who was waiting in a queue to be sworn in.

Since 2011, Moldovan citizens have had the option to note their ethnicity in their birth records. In order to escape poverty, study or work in the West, reunite family members or because of Romanian ethnicity, more than 23,000 Moldovans having ancestry in Bessarabia became citizens of Romania in 2010.

The director of the National Citizenship Agency of Romania's Interior Ministry said:

There is, in fact, a historic readjustment intended without recalling that the Ribbentrop/Molotov pact ${ }^{47}$ granted citizenship to Moldovans who could demonstrate having kinship with family in the third degree (grandparents born in Romania). So, it is required to present the birth record or death certificate of the ancestor, who thereby can be demonstrated to have been born within the territory claimed by Romania until $1940^{48}$.

${ }^{45} \mathrm{Cf} . \quad<$ http://romanialibera.ro/actualitate/eveniment/de-10-ori-mai multe-cereri-pentru-cetateniaromana-196678.html>

46 "Evadarea din Chisinau spre Europa Romania libera", 9 Mai, 2011. Disponible in: <http://www. romanialibera.ro/exclusiv-rl/reportaj/evadarea-din-chisinau-spre-europa-cum-devin-moldoveniiromani-cu-acte-in-regula-224748.html>.

47 The Ribbentrop-Molotov Treaty, signed by Nazi Germany and the Soviet Union in 1939, allowing the annexation of Bessarabia, northern Bucovina, and the Hertza region by the USSR.

${ }^{48}$ Interview, GN, 27 April 2007, headquarters of National Citizenship office of the Romanian Interior Ministry. 
Of the persons interviewed, $90 \%$ note their desire to circulate freely within Europe.

The border causes problems, with document controls. All of the countries control us. In Romanian, in Hungary...every border, for us, means another control. So it is normal that people who have no visa should cross the border illegally, like us $^{49}$.

Interviewees, especially women, make reference to the difficulties they encountered in the destination country $(70 \%$ of those interviewed) because they did not have the required documents for the destination country, and because they were employed as domestics and caregivers.

I was not able to get legalized. They locked me up because I was illegal, and then they deported me. It was bad. For women, above all, there is great danger. Why does life have to be so bad for us $?^{50}$

The idea of negotiating a visa-free liberalization regime with the $\mathrm{EU}^{51}$ has become one of the most important objectives of the Moldovan authorities. The success or failure to achieve this objective in the coming years will have a big impact on how the EU is going to be perceived by Moldovans. A potential success will certainly empower the pro-European and democratic forces, give valuable incentives for accelerating reform processes, help Moldova to become attractive in the eyes of its citizens that live in the Transnistrian separatist region and strengthen the EU status and role in the country.

\section{Finding survival strategies: mobility and return for development}

In the second part, the interviews related their mobility experiences and return. Moldova's business environment provides limited opportunities for investment. Migrants often encounter difficulties when re-integrating into Moldovan society, often lacking the infrastructure, opportunities and support available to them previously in the countries of migration. Despite these conditions, many migrants who possess some capital for investment, have entrepreneurial spirit and are willing to undertake some risks choose to invest in Moldova. Of the 44 persons interviewed, 27 had begun to launch their own business. The remaining 17 wanted to emigrate again. The situation for them continued to be difficult because they had exhausted the resources saved during the period of their emigration and were unemployed at the

\footnotetext{
${ }^{49}$ Interview, 23 July 2010. Male returning from Italy, age 43, Anenii Noi.

${ }^{50}$ Interview, 16 July 2010. Female returning from Greece, age 50, Hincesti.

${ }^{51}$ EU Commissioner welcomes Moldova's progress on visa free regime agenda. Söderköping Process. Disponible in: <http://soderkoping.org.ua/page28732.html>.
} 
time of the interview. We can say that these were cases of marginal return, in vulnerable situations.

Investments were made for the most part with income that had been accumulated during the time spent outside of Moldova or, in just a few (3) cases, from programs coordinated by the IOM: the Agency of Migration and Development ${ }^{52}$ and PARE $1+1^{53}$.

According to the interviewees, businesses are started with very few resources that do not surpass more than a few hundred Euro. The largest sum invested amounted to 50,000 Euro. There were also 4 cases of couples in which one partner (generally, a woman) worked outside of the country while the male partner managed the business.

The interviewees related how extremely difficult it is to start a business in Moldova because of the "corrupt and excessively bureaucratic" environment there. In their interviews, they spoke of their attempts to start businesses with their former employers in Italy or Spain, while complaining about the established barriers to foreign investment in Moldova.

This study revealed situations in which the financial, human and social capital acquired by Moldovans abroad is instead channelled towards, for example, Romanian border communities. Even if few such cases exist at the moment, there is a potential for these numbers to increase in the future, especially since obtaining Romanian citizenship by Moldovans has become easier.

I tried to start a business here in Hincesti but, in the end, we took it to Galati. There are lots of hair stylists, pharmacies, and food stores that are in Romania because there is less bureaucracy there ${ }^{54}$.

Another difficulty that interviewees point out is the high price of electricity. Interviewees in Anenii Noi and Varnita say it "is better to open a business in Bender, because in Transnistria energy is cheaper."

For return migrants, the decision to start a business is frequently hindered by a failure to re-integrate into the Moldovan labor market. The failure of some entrepreneurial activities can be attributed to many factors, the two most

\footnotetext{
${ }^{52}$ IOM Mission to Moldova is implementing a three-year project, "Supporting the implementation of the migration and development component of the EU-Moldova Mobility Partnership," in order to minimize the negative effects of migration and to harness the benefits for development purposes.

${ }^{53}$ On November 22, 2010, the pilot Program on Attracting Remittances into the Economy PARE 1+1 was launched. The program aims to stimulate the transfer of remittances through official channels, transfer knowledge and know-how, facilitate the access of migrants to funds, and create new places of work in Moldova.

${ }^{54}$ Interview, 17 July 2010. Male returning from Italy, age 51, Hincesti.
} 
important of which are 1) a lack of access to information (particularly in rural areas) and 2) difficulties in the expansion and creation of businesses.

As a result, many migrants resort to repeat migration. But to emigrate again, under the current conditions, is difficult ${ }^{55}$.

Once I returned without papers...And I left again, paid 3,000 Euro, and the route was very dangerous; my life was in the balance. There are thousands of people in Moldova who have been unable to return, who suffer and are cold and hungry. It is because Moldova is throwing us out that we have to leave ${ }^{56}$.

Interviewees point out the importance of the human, social, and even psychological and cultural capital they acquired during the process of migration. This has an impact on the way of doing things and how they perceive themselves and others. It has a positive impact on the host country as well.

If it were possible to accomplish things in our country, about $90 \%$ of the people would return. We like Europe and want to live as in Europe, but we have to learn how to behave as they do in Europe. Because it is necessary that in a country businesses should function, that taxes are paid and that people are well. But here in our country, it is the bars, cafés and restaurants that work. Nothing else. Corruption is overwhelming. In fact, it is we the returning emigrants who have to change things. To get united and put change into effect ${ }^{57}$.

"It is important for there to be cross-border mobility towards the EU", said the IOM coordinator of Moldova, because in comparison to emigration to Canada, it is a process that produces benefits for Moldova in terms of remittances, economic growth, return, the human factor and the change in the mentality of the people who emigrate and their families.

\section{Europe \\ Building symbolic bridges: from Moldovan identity to a sense of}

The last part of this study concerns identity and a sense of Europe. Returning emigrants believe that Moldova must maintain and strengthen the hallmarks of its identity, but at the same time, the experience of mobility has instilled the idea of belonging to Europe and that their country should and

\footnotetext{
${ }^{55}$ According to the Barometer published by the Public Policy Institute, in May 2011 approximately $80 \%$ of the population had not ever travelled to an EU country (except for Romania). Only $11 \%$ indicated that they would travel to an EU country for employment in the following year if allowed to circulate without a visa. Cf. <http://ipp.md/libview.php?l=ro\&idc=150\&id=562>.

${ }^{56}$ Interview, 10 July 2010. Female returning from Portugal. Age 45. Straseni.

${ }^{57}$ Interview, 12 July 2010. Male returning from Ireland. Age 48. Straseni.
} 
must orient itself towards Europe. Thus, identity and integration are two sides of the same coin ${ }^{58}$.

However, despite favoring Moldova's entry into Europe, they discard any possibility of uniting with Romania. They want to have Romanian citizenship by right, but none of those interviewed self-identified as Romanian. Eighty percent of them declared that they are Moldovans who speak Romanian, while $20 \%$ say they speak Moldovan.

I speak Russian but I am a Moldovan of Romanian origin: I was educated in two languages. When speaking Spanish, I have to think in Romanian first. Not with Russian, because I learned as a youngster. I am a Moldovan, not a Romanian. There has been talk about union, but we are not a country. If there were no borders, life would be better. Yes, the border should be lifted, but if you ask me about union with Romania, I would say clearly no...We want the EU, not Romania ${ }^{59}$.

Public opinion in host countries about Romanian immigrants is negative and is attributed to crime, corruption and human trafficking. Women who were interviewed said that they had been victims of Romanian criminal organizations using fraudulent passports and visas.

However, upon being asked about the influence of Russia, Moldovans seem to be inclined to both Russia and the EU.

We have to value our history, and the history of the EU, and Russia. We were under the Romanians and the Russians. When I graduated from the Institute in the 1970s, I didn't speak Russian. And without Russian, you couldn't do anything. I learned it, conducted my education in Russian, and later the Romanian issue came up. We are between Russia and the $\mathrm{EU}^{60}$.

Since attaining independence in 1991, Moldova has experienced complex relationships with its neighbors, including Russia and the EU. The analysis shows that Moldova, forming part of the contested neighborhood of the EU and Russia, has been trying to balance between the two powers, playing on their contradictions and availability.

According to the Barometer, $65 \%$ of the people are in agreement with Moldova's integration with the EU, while $15 \%$ are undecided. Fifty-seven percent of those interviewed believe that Moldova's principal strategic partner should be the Russian Federation while $62 \%$ want neutrality for their country.

\footnotetext{
${ }^{58}$ CAMIA, Valeria. Normative Discussions on European Identity: a puzzle for Social Science?

${ }^{59}$ Interview, 20 July 2010. Male returning from Spain. Age 48. Anenii Noi.

${ }^{60}$ Interview, 22 July 2010. Male returning from Great Britain. Age 50. Anenii Noi.
} 
In comparison to these national statistical data, we note the outspokenness of returning emigrants who oppose Russian influence over their country's future, associating Russia with the past and backwardness:

I don't want to think about Russia; it would be like going backwards. I have always thought that Europe is the solution. I say that the people who left could see how life is abroad and can apply what they have seen and heard ${ }^{61}$.

There are, therefore, two perceptions: one is pro-Russia while the other is pro-Europe, even while they are not mutually exclusive. This is specific to Moldova, which is in a constant struggle to create an identity, to believe in it as a symbol of unity within diversity.

There is a dilemma. Probably, we are pro-Europe for the most part. The current government takes action. The EU is open and there will be something positive. But another important factor must not be forgotten: our economic market is Russia. We need to exercise diplomacy so as to maintain both relationships, because Russia offers us facilities, free circulation and a common language. This is the policy of small countries: a policy of sacrifice ${ }^{62}$.

Moldova is in the midst of a political and economic transition, while its civil society is still defining itself. In order to get closer to Europe, besides mobility and the return of its émigrés, Moldova must overcome its low level of development and leave behind the legacy of the USSR and find a way to get its citizens to become active in the process of political development ${ }^{63}$.

\section{Conclusion: Waiting for Europe}

As has been stated metaphorically by Johnson et alii, "...rather than neutral lines, borders are often pools of emotions, fears and memories that can be mobilized apace for both progressive and regressive purposes" ${ }^{\prime \prime 4}$. Newman ${ }^{65}$ reminds us that the study of narratives and discourse is central to an understanding of all types of boundaries. For Moldova, the border is linked to complex symbols and emotions. Following the creation of the country in 1991, Moldovans who were formerly residents of the USSR are

\footnotetext{
${ }^{61}$ Interview, 23 July 2010. Female returning from Spain. Anenii Noi.

${ }^{62}$ Interview, 13 April 2010. Local Counsellor, Anenii Noi.

${ }^{63}$ Note: in the local general elections of June 2011, voter participation stood at $53 \%$.

${ }^{64}$ JOHNSON, Corey; JONES, Reece; PAASI, Anssi; AMOORE, Louise; MOUNTZ, Alison; SALTER, Mark; RUMFORD, Chris. Interventions on rethinking 'the border' in border studies.

${ }^{65}$ NEWMAN, David. The lines that continue to separate us: borders in our 'borderless' world.
} 
trying to re-define themselves as citizens of Moldova within the context of the $\mathrm{EU}$ while creating a sense of being European.

Firstly, the geopolitical situation on the periphery of the region influences the sense of identity on the part of people who note that their country needs EU support.

On one hand, Moldovans who emigrate (whether they are of Russian, Ukrainian, or Romanian ethnicities) are by necessity united by the experience of migration. They agree that Europe is part of their Moldovan identity, and therefore feel they are a part of Europe. Mobility instilled in them a sense of being closer to Europe.

On the other hand, migrants exhibit a variety of different experiences of crossing the EU border and point out the isolation and marginalization that they suffer because of a border that separates them from the rest of Europe. As such, the border both unites and isolates them, integrates and fragments them, at the same time. The difficulty of both juridical and labor integration within the countries of the EU impels emigrants to return but with the conviction that their country must become integrated into the system of western values.

Moldovans live, therefore, with a dual 'otherness': that of their own country, where they are confronted by various identities, and that of Europe. We emphasize Moldovan migrants' ability as outsiders on the margins of Europe to live with different kinds of belonging and have a "multidimensional belonging"66. Defying the border, they adopt elements of European identity that they use to influence the thinking of their fellow citizens ${ }^{67}$. Therefore, it is in Moldova that they construct their sense of Europe.

Secondly, for Moldovans, migration is a life strategy. While remittances are for now an important advantage, it has been demonstrated that emigrants' return and their opening of businesses may help to strengthen the ties between mobility and development. In spite of the numerous difficulties and challenges facing small enterprises, migrants remain generally optimistic, and trust that decision makers will change their attitudes towards small-scale producers. They hope addressing these issues will help them to bring back home the financial, human and social capital obtained from abroad.

Although there is a high degree of social cohesion between Moldovans abroad on an individual level, there is limited social cohesion among the community of Moldovans abroad as a whole. These formal groups have the

\footnotetext{
${ }^{66}$ MAY, Vanessa. Self, Belonging and Social Change.

${ }^{67}$ BROWNING, Christopher; CHRISTOU, Geoge. The constitutive power of outsiders: The European neighbourhood policy and the eastern dimension.
} 
potential to become involved in the development of their home country, although their actual level of engagement in such activities remains limited. But they are confident that they can offer new knowledge and therefore help in the development of their country.

In conclusion, we find that the multi-ethnic identity of Moldova, by means of its mobility, brings richness to the culture of Europe. Moldovans defend a Moldovan identity within a European context by seeking to leave behind their marginalization and become integrated with European values. Moldovan discourse is transformed into a European discourse through a mobility that at the same time is the means by which Moldova will become closer to Europe. Therefore, the EU has the ability to export norms, values, and models to its "outsiders"68, while at the same time immigrants offer values that affect and enrich their identity.

\section{References}

AGNEW, John. Borders on the mind: re-framing border thinking. Ethics and Global Politics, v. 1, n. 4, 2008, p. 175-191.

AMASSARI Savina; BLACK, Richard. Harnessing the potential of migration and return to promote development: applying concepts to West Africa. Geneva: IOM Migration Research Series, 2001.

BARTH, Fredrick. The Analysis of Culture in Complex Societies. Ethnos, v. 54, n. 3-4, 1989, p. 120-142.

BECKFIELD, Jason. European Integration and Income Inequality. American Sociological Review, v. 71, n. 6, 2006, p. 964-985.

BLACK, Richard; GENT, Saskia. Sustainable return in post-conflict contexts. International Migration, v. 44, n. 3, 2006, p. 15-38.

BROWNING, Christopher; CHRISTOU, George. The constitutive power of outsiders: The European neighbourhood policy and the eastern dimension. Political Geography, v. 29, 2010, p. 109-118.

BRUTER, Michael. Citizens of Europe? The Emergence of a Mass European Identity. Basingstoke: Palgrave Macmillan, 2005.

CAMIA, Valeria. Normative Discussions on European Identity: a puzzle for Social Science? Perspectives on European Politics and Society, v. 11, 2010, p. 109-118.

CHAPMAN, Murray; PROTHERO, Mansell. Themes on circulation in the Third World. International Migration Review, v. 17, n. 4, 1983, p. 597-632.

CHINN, Jeff. Moldovans: Searching for Identity. Problems of Post Communism, v. 44, 1997, p. 43-51.

COOPER, Anthonny; RUMFORD. Monumentalising the Border: Bordering Through Connectivity. Mobilities, v. 8, n. 1, 2013, p. 107-124.

${ }^{68}$ LAVENEX, Sandra. EU external governance in a wider Europe. 
COUTIN, Susan. Nations of Emigrants: Shifting Boundaries of Citizenship in El Salvador and the United States. Ithaca, NY: Cornell University Press, 2005.

DE HAAS, Hein. The migration and development pendulum: a critical view of current research and policy. International Migration, v. 50, n. 3, 2012, p. 8-25.

. Migration and development: a theoretical perspective. International Migration Review, v. 44, n. 1, 2012, p. 227-264.

FAIST, Thomas. Migrants as Transnational Development Agents: An Inquiry into the Newest Round of the Migration-Development Nexus. Population, Space and Place, v. 14, 2008, 21-42.

FLIGSTEIN, Neil; MÉRAND, Frederic. Globalization or Europeanization? Evidence on the European Economy since 1980. Acta Sociologica, v. 45, n. 1, 2002, p. 7-22.

FOURON, Geoges; GLICK SCHILLER, Nina. All in the Family: Gender, Transnational Migration, and the Nation-State. Identities: Global Studies in Culture and Power, v. 7, n. 4, 2001, p. 539-582.

GLASER, Barney; STRAUSS, Anselm. The discovery of grounded theory: strategies for qualitative research. New York: Aldine, 1967.

GLICK SCHILLER, Nina; BASCH, Linda; SZANTON BLANC, Christina. Transnationalism: A new analytic framework for understanding migration. In GLICK SCHILLER, Nina; BASCH, Linda; SZANTON BLANC, Christina (eds.). Towards a transnational perspective on migration: Race, class, ethnicity and nationalism reconsidered. New York: New York Academy of Sciences, 1992, p. 1-24.

GOULD, David. Immigrant Links to the Home Country: Empirical Implications for US Bilateral Trade Flows. The Review of Economics and Statistics, v. 76, n. 2, 1994, p. 302-316.

GRUNDY, Sue; JAMIESON, Lynn. European Identities: From Absent-Minded Citizens to Passionate Europeans. Sociology, v. 41, n. 4, 2007, p. 663-680.

INTERNATIONAL Organization of Migration Moldova. Disponible in: <http://www. iom.md/index.php/en/programs/migrationa-development $>$, 2011. Accessed in 17.01.2013.

HADZIGEORGIOU, Andreas. Migration as Trade Facilitation: Assessing the Links between International Trade and Migration. The B.E. Journal of Economic Analysis \& Policy, v. 10, n. 1, 2010, p. 1-33.

JANSEN, Marion; PIERMARTINI, Roberta. Temporary Migration and Bilateral Trade Flows. World Economy, v. 32, 2009, p. 735-753.

JOHNSON, Corey; JONES, Reece; PAASI, Anssi; AMOORE, Louise; MOUNTZ, Alison; SALTER, Mark; RUMFORD, Chris. Interventions on rethinking 'the border' in border studies. Political Geography, v. 30, n. 2, 2011, p. 61-69.

KING, Richard; POVRZANOVI Frykman; VULLNETARI, Jullie. Migration, transnationalism and development on the Southeastern flank of Europe. Southeast European and Black Sea Studies, v. 13, n. 2, 2013, p. 125-140. 
. Generalizations from the history of return migration. In $\mathrm{GHOSH}$, Bimal (ed.). Return Migration. Journey of Hope or Despair? Geneva: IOM/UN, 2001.

KING, Charles. The Moldovans: Romania, Russia, and the Politics of Culture. Stanford: Hoover Institution Press, 2000.

. Marking time in the middle ground: contested identities and Moldovan foreign policy. Journal of Communist Studies and Transition Politics, v. 19, n. 3, 2003, p. 60-82.

LAVENEX, Sandra. EU external governance in a wider Europe. Journal of European Public Policy, v. 11, n. 4, 2004, p. 680-700.

LEVITT, PEGGY; LAMBA-NIEVES, Deepak. Social Remittances Revisited. Journal of Ethnic and Migration Studies, v. 37, n. 1, 2011, p. 1-22.

MARCU, Silvia. Opening the Mind, Challenging the Space: Cross-border Cooperation between Romania and Moldova. International Planning Studies, v. 16, n. 2, 2011, p. 109-130.

. The Geopolitics of the Eastern Border of the European Union: The Case of Romania-Moldova-Ukraine. Geopolitics, v. 14, n. 3, 2009, p. 409-432.

MAY, Vanessa. Self, Belonging and Social Change. Sociology, v. 45, n. 3, 2011, p. 363-378.

NEWMAN, David. The lines that continue to separate us: borders in our 'borderless' world. Progress in Human Geography, v. 30, n. 2, 2006, p. 143-161.

PORTES, Alejandro; GUARNIZO, Luis; LANDOLT, Patricia. The Study of Transnationalism: Pitfalls and Promise of an Emergent Research Field. Ethnic and Racial Studies, v. 22, n. 2, 1999, p. 217-237.

RISSE, Thomas. European institutions and identity change: what have we learned? In HERRMANN, Richard; RISSE, Thomas; BREWER, Marilynn (eds.). Transnational Identities: Becoming European in the EU. Lanham, Md: Rowman \& Littlefield, 2004, p. 247-271.

ROUSE, Roger. Mexican migration and the social space of post-modernism. In INDA Jonathan Xavier; ROSALDO Renato (eds.). The anthropology of globalization: a reader. Malden, MA: Blackwell Publishers, 2002, p. 157-171.

ROTHER, Nina; NEBE, Tina. More Mobile, More European? Free Movement and EU identity. In FAVELL, Adrien; RECCHI, Ettore (eds.). Pioneers of European Integration: Citizenship and Mobility in the EU. Cheltenham: Edward Elgar, 2009, p. 120-155.

RUSNAC, Gheorghe; MOŞNEAGA, Valeriu; MORARU, Victor; ŢURCAN, Valentin. Faţetele unui proces: migraţia forţei de muncă din Republica Moldova în Italia. Chişinău: Prim, 2011.

SANDERSON, Matthew; KENTOR, Jeffrey. Foreign direct investment and international migration: A cross-national analysis of less-developed countries, 1985-2000. International Sociology, v. 23, n. 4, 2008, p. 514-539. 
Mobility, return for development and sense of Europe: narratives of Moldavian immigrants

SKELDON, Ronald. Migration and development over twenty years of research: progress and prospects. In AUDEBERT Cedric; DORAÏ Mohamed (eds.). Migration in a Globalised World: New Research Issues and Prospects. Amsterdam: Amsterdam University Press, 2010, p. 145-159.

VAN HOUTUM, Henk. Human blacklisting: the global apartheid of the EU's external border regime. Environment and Planning D, v. 28, 2010, p. 957-976.

VAN HOUTE Marieke; Davids TINE. Development and return migration: from policy panacea to migrant perspective sustainability. Third World Quarterly, v. 29, n. 7, 2008, p. 1411-1429.

VERTOVEC, Steve. Conceiving and Researching Transnationalism. Ethnic and Racial Studies, v. 22, n. 2, 1999, p. 447-460.

\section{Abstract}

Mobilidade, retorno para o desenvolvimento e sentido de Europa: narrativas de imigrantes moldavos que retornam da União Europeia

Este artigo associa a migração, a mobilidade além-fronteiras e o retorno para o desenvolvimento, enraizados em termos de identidade e de abordagem ao sentido da Europa. Ao se considerar as mudanças globais que estão ocorrendo na Moldávia, analisam-se as percepções de mobilidade, retorno e identidade dos Moldavos emigrantes em países da União Europeia. Com base em abordagem multidisciplinar e em técnica qualitativa de entrevista em profundidade, este artigo busca avaliar como a mobilidade e o retorno podem apoiar a mudança e o desenvolvimento social do país, e argumenta que as pessoas, que atravessam as fronteiras da UE e vivem a experiência da emigração, adquirem uma mentalidade pró-europeia.

Palavras-chave: mobilidade, fronteira, Moldávia, desenvolvimento, retorno, União Europeia. 